\title{
Properties of Cement Brick Containing Expanded Polystyrene Beads (EPS) And Palm Oil Fuel Ash (POFA)
}

\author{
N.A. Kamarulzaman ${ }^{1}$, S.H. Adnan ${ }^{1}$, K.A. Mohd Sari ${ }^{1}$, M.H. Osman ${ }^{1}$, M.L. Ahmad Jeni ${ }^{1}$, \\ M.S. Abdullah ${ }^{1}$, P. Ang Soon Ern ${ }^{1}$, N.F. Yahya ${ }^{1}$, N.I.M Yassin², M.N.A. Wahee Anuar ${ }^{3}$ \\ ${ }^{1 *}$ Faculty of Engineering Technology, Universiti Tun Hussein Onn Malaysia, \\ Branch Pagoh, Panchor Muar, Johor, Malaysia. \\ ${ }^{2}$ Faculty of Civil and Environmental Engineering, Universiti Tun Hussein Onn Malaysia, \\ Parit Raja,Batu Pahat, Johor, Malaysia. \\ ${ }^{3}$ Melayu Jati Enterprise, Batu Pahat, Johor Malaysia.
}

Received 15 September 2018; accepted 1 December 2018; available online 30 December 2018

DOI: https://10.30880/jst.2018.10.04.008

\begin{abstract}
This paper assesses the mechanical properties of cement brick containing Expanded Polystyrene Beads (EPS) and Palm Oil Fuel Ash (POFA) as partial replacement of sand and Ordinary Portland Cement (OPC). The aim of this research are to determine the mechanical properties of brick containing EPS and POFA as partial replacement of sand and OPC. The dosage for EPS replacement is $20 \%, 30 \%, 40 \%$ and $50 \%$ EPS whereas $5 \%, 10 \%, 15 \%, 20 \%$ and $25 \%$ of POFA replacement. The mechanical properties of the bricks are density, compressive strength and water absorption. The bricks with $30 \%, 40 \%$ and $50 \%$ EPS replacement have density below $1680 \mathrm{~kg} / \mathrm{m}^{3}$ which considered as lightweight brick. The brick with $50 \%$ EPS replacement recorded lowest density which is $1328 \mathrm{~kg} / \mathrm{m}^{3}$ while $1629 \mathrm{~kg} / \mathrm{m}^{3}$ for the brick with $25 \%$ POFA replacement at 56-days of curing. The water absorption testing for these brick are between 7.20\%-18.19\%. Brick with 0\% POFA and 50\% EPS replacement has the lowest water absorption properties whereas brick with 25\% POFA and $0 \%$ EPS replacement has the highest water absorption properties.
\end{abstract}

Keywords: Expanded polystyrene beads; Palm oil fuel ash; Lightweight Brick; Recycle Materials; Compressive Strength.

\subsection{Introduction}

Bricks are considered as a significant and strongest building materials that had been used over the years. Bricks are durable and required low maintenance (Rahman et al., 2014). Singh et. al. (2017) stated that the popularity of brick as a construction material are because of its good heat insulation properties, high compressive strength, easy availability, good soundness, durability, and the low cost. About 1391 billion units of brick were produced from worldwide in a year and the production is expected to be rising as demanded (Zhang, 2013).

Nowadays, the usage of the Ordinary Portland Cement (OPC) concrete industry due to development of infrastructure produce large amount of cement because of high demand for concrete as the construction project has increased. According to Alsubari et. al. (2016), environmental and greenhouse gas problem is caused by the cement production process which contributes about $7 \%$ of the global $\mathrm{CO}_{2}$ emission. According to Tabassum and Khadwal (2015), the Portland cement production leads to environmental pollution due to carbon dioxide emission. Due to this issue, the waste from burning process suitable to be used as cement replacement material to improve the properties of mortar or concrete (Zeyad et. al., 2016). POFA is recognized as suitable material for cement replacement. This is because POFA helps in reducing the environment waste problem and utilization of POFA as pozzolanic material to replace cement will enhance the sustainability (AL-Oqla and Sapuan, 2014). Malaysia is second largest producer in palm oil industry (Raut and Gomez, 2016). According to Munir et. al. (2015), POFA is a solid waste byproduct in the form of ash attained from the burning of palm oil husk and palm kernel in palm oil boiler from palm oil mill.

Besides another suitable material for replacement cement in brick is EPS. Ling and Teo (2012) in a study state that EPS is polystyrene in raw beads that expanded after it being steam-heated. EPS is light, has good 
energy absorbing characteristic and good thermal insulator. In the other hand, EPS is chosen as replacement material because of its lightweight properties that could reduce the weight of concrete brick equivalent to it density. Besides, EPS is frequently used for packaging and for construction as it is light, rigid, good thermal insulation and high impact resistance. According to Musab (2016) and Adnan et. al. (2017), EPS is widely used in packaging world but after it had been used, it becomes waste that cannot decompose naturally. Hence, the main objective of this research is to assesses the mechanical properties of cement brick containing expanded polystyrene beads (EPS) and palm oil fuel ash (POFA) as partial replacement of sand and ordinary portland cement (OPC)

Lightweight brick have some excellent characteristics such as lower density, higher specific strength, better thermal insulation and greater energy absorption which can be obtain by replacing standard aggregate totally or partially by lightweight aggregate (Yi Xu et. al., 2012).

\section{Experimental Study}

\subsection{Materials}

The materials used for production brick are Ordinary Portland Cement (OPC), fine aggregate (sand), palm oil fuel ash, expanded polystyrene beads, water and superplasticizer.

\subsubsection{Ordinary Portland Cement (OPC)}

Ordinary Portland cement referred to Malaysia Standard Specification MS 522: Part 1: 2003 with the particle density of the cement is 1254 $\mathrm{kg} / \mathrm{m}^{3}$.

\subsubsection{Fine aggregate (sand)}

Fine aggregate which is natural sand passing through $2 \mathrm{~mm}$ sieve, dry in oven for 24 hours at $100^{\circ} \mathrm{C}$ and undergo $10 \%$ fine value test The particle density of the sand is $1597.5 \mathrm{~kg} / \mathrm{m}^{3}$.

\subsubsection{Palm oil fuel ash (POFA)}

POFA was collected from palm oil processing factory at Pontian, Johor by burning of palm oil husk and palm oil kernel in the boiler. The POFA dry in oven at the temperature of $100^{\circ} \mathrm{C} \pm$ 5 for 24 hours and sieve to size of passing $300 \mu \mathrm{m}$. The density of this POFA is 987.49 $\mathrm{kg} / \mathrm{m}^{3}$.

\subsubsection{Expanded polystyrene beads (EPS)}

EPS was in range size between $1.18 \mathrm{~mm}$ to 2.36 $\mathrm{mm}$ and supplied by ST Polyfoam Industries Sdn. Bhd. located in Sri Gading, Batu Pahat. It particle density is $17.92 \mathrm{~kg} / \mathrm{m}^{3}$. The bulk density and specific gravity of the EPS is 30 $\mathrm{kg} / \mathrm{m}^{3}$ and 0.01 respectively.

\subsubsection{Superplasticizer}

Superplasticizer is an additional material to improve the workability of the mix. The superplasticizer use is from ESTOP brand. The amount of superplasticzer need to use is $8 \mathrm{ml}$ per $1 \mathrm{~kg}$ of cement.

\subsection{Sample preparation}

Sample size is according to standard brick size of $215 \mathrm{~mm} \times 102.5 \mathrm{~mm} \times 65 \mathrm{~mm}$ as shown in Fig. 1 for density testing, compressive strength testing, and water absorption testing. This dimension is according to BS 4729-1990 standard for brick. Fig. 2 showm the mould used to produce the brick according to the stated size. Various mixes of cement mortar with different percentage of EPS and POFA has been prepared to produce bricks. The mortar mix is design based on 1:3 mixes complies with Malaysia Standard for bricks production. Water cement ratio of mixes is 0.5 . Control sample without any replacement of EPS and POFA also has been cast to compare with other samples with replacement of EPS and POFA. Table 1 shows the mix design of cement mortar with various percentages of EPS and POFA.

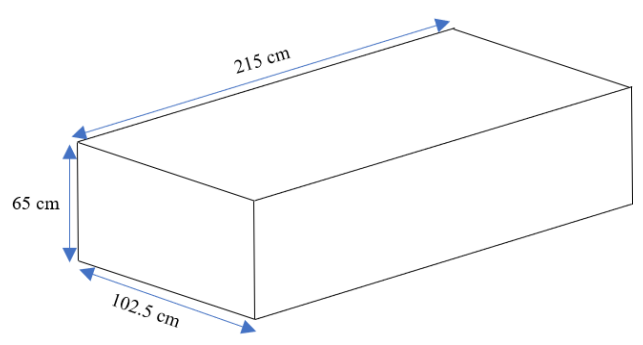

Fig. 1 Brick dimension. 


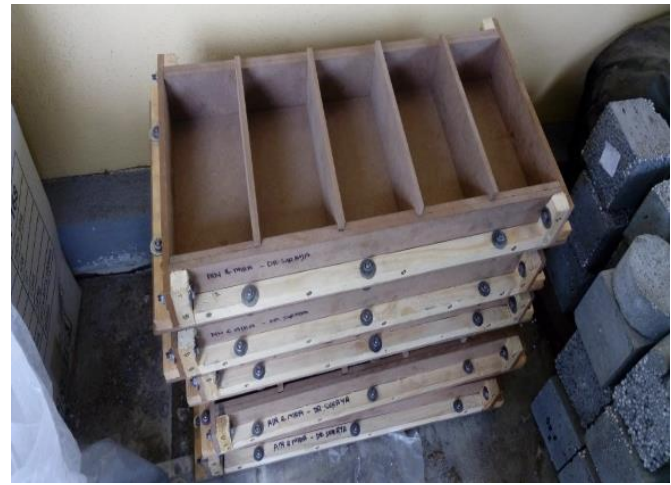

Fig. 2 Brick Mould.

\subsubsection{Mixing and Casting}

Batching of mortar has been conducted manually. All the materials has been mix evenly. Fig. 3 to Fig. 6 show the process to produce the bricks.

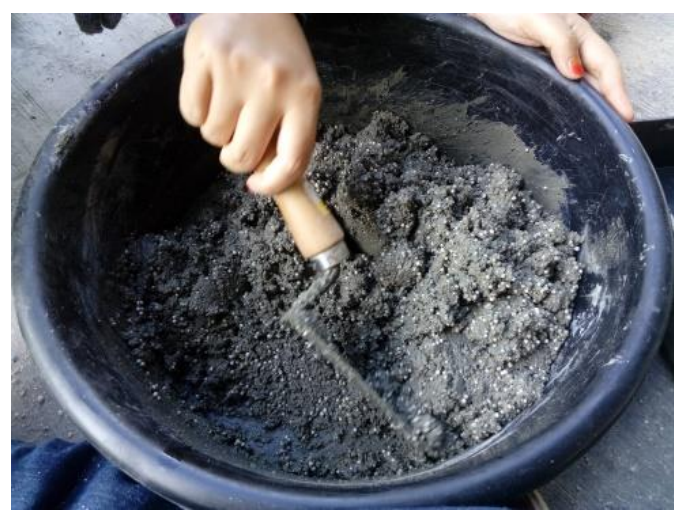

Fig. 3 Mixing process.

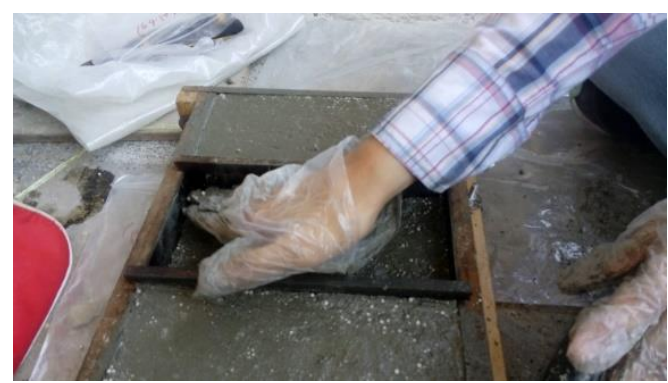

Fig. 4 Compacting the mortar inside the mould using hand tamping

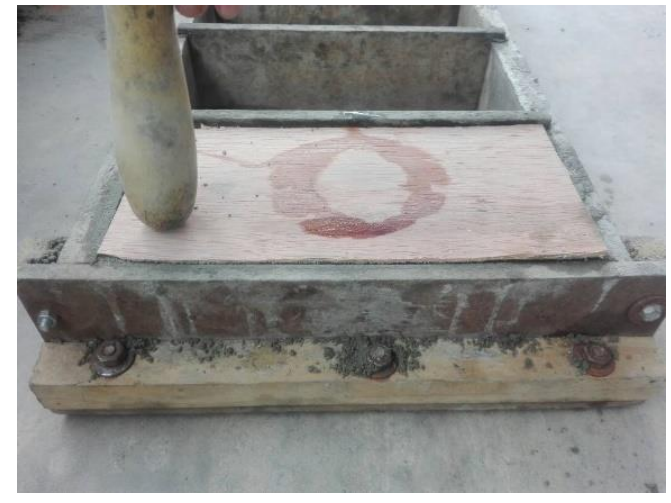

Fig. 5 Flatting the surface of the brick with a plywood to prevent uneven surface.

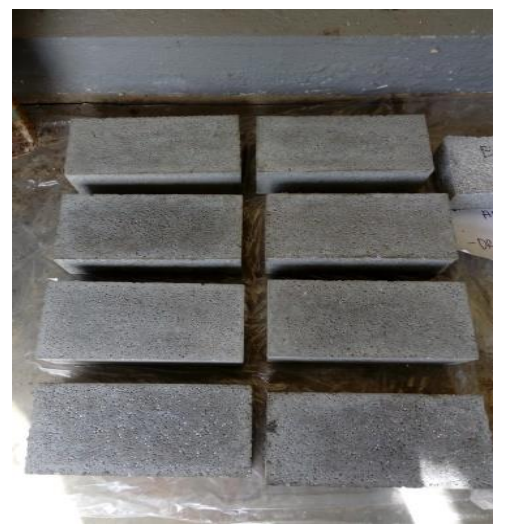

Fig. 6 Demoulded brick in curing period before testing day.

The mortar is compacted inside the mould using hand tamping method compliance to ASTM C109/C 109M-07 Standard. Fig. 7 shows the order of tamping in moulding of test specimen. This process must be conducted within a total elapsed time of not more than 2 min and $30 \mathrm{~s}$ after completion of the original mixing of the mortar batch. The mortar is fill layer by layer. Each layer is in about $25 \mathrm{~mm}$ and tamp 32 times in about $10 \mathrm{~s}$ in 4 rounds.

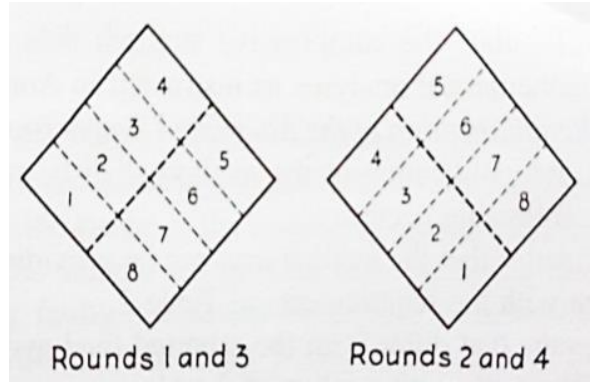

Fig. 7 Order of tamping in moulding of test specimen. 
Table 1 Mix design of cement mortar with various percentages of EPS and POFA.

\begin{tabular}{|c|c|c|c|c|c|c|}
\hline \multirow{2}{*}{ EPS } & \multicolumn{5}{|c|}{ POFA } & \multicolumn{2}{|c|}{$15 \%$} & $20 \%$ \\
\cline { 2 - 7 } & $0 \%$ & $5 \%$ & $10 \%$ & $0.85: 0.15: 3$ & $0.8: 0.2: 3$ & $0.75: 0.25: 3$ \\
\hline $20 \%$ & $1: 2.4: 0.6$ & $0.95: 0.05: 2.4: 0.6$ & $0.9: 0.1: 2.4: 0.6$ & $0.85: 0.15: 2.4: 0.6$ & $0.8: 0.2: 2.4: 0.6$ & $0.75: 0.25: 2.4: 0.6$ \\
\hline $30 \%$ & $1: 2.1: 0.9$ & $0.95: 0.05: 2.1: 0.9$ & $0.9: 0.1: 2.1: 0.9$ & $0.85: 0.15: 2.1: 0.9$ & $0.8: 0.2: 2.1: 0.9$ & $0.75: 0.25: 2.1: 0.9$ \\
\hline $40 \%$ & $1: 1.8: 1.2$ & $0.95: 0.05: 1.8: 1.2$ & $0.9: 0.1: 1.8: 1.2$ & $0.85: 0.15: 1.8: 1.2$ & $0.8: 0.2: 1.8: 1.2$ & $0.75: 0.25: 1.8: 1.2$ \\
\hline $50 \%$ & $1: 1.5: 1.5$ & $0.95: 0.05: 1.5: 1.5$ & $0.9: 0.1: 1.5: 1.5$ & $0.85: 0.15: 1.5: 1.5$ & $0.8: 0.2: 1.5: 1.5$ \\
\hline
\end{tabular}

\subsection{Testing Method}

All the brick samples have been test with density, compressive strength and water absorption testing. All the tests has been conduct according to standards as stated in Table 2.

Table 2 List of standards used to conduct the tests.

\begin{tabular}{|c|c|c|}
\hline Properties & Laboratory Test & Standards \\
\hline & Density of & BS EN \\
samples & $12390-7$ \\
\cline { 2 - 3 } Mechanical & Compressive & ASTM \\
properties of & Strength & C109-07 \\
\cline { 2 - 3 } materials & Water & BS 1881: \\
& Absorption & Part 122 \\
\hline
\end{tabular}

\subsection{Results and Discussion}

\subsection{Density}

The actual casting process then proceed with $0 \%, 20 \%, 30 \%, 40 \%$ and $50 \%$ of EPS replacement and $0 \%, 5 \%, 10 \%, 15 \%, 20 \%$ and $25 \%$ POFA replacement for 7, 28 and 56 day air-curing. The density shows the reductions by addition of EPS and POFA. The higher the EPS and POFA replacement, the lower the density of the brick. This result has correlation due to the raw material density. The EPS has a very low density which is $17.92 \mathrm{~kg} / \mathrm{m}^{3}$. Besides, POFA also has lower density than OPC which is $987.49 \mathrm{~kg} / \mathrm{m}^{3}$. This clearly will affect the density of bricks. The number of curing days does not really affect the density. Its only effect little scale of the density difference. The longer the curing, the lower the density. Most of the brick with $30 \%, 40 \%$ and $50 \%$ EPS replacement is considered as lightweight brick as its density is lower than $1680 \mathrm{~kg} / \mathrm{m}^{3}$. Some brick with $20 \%$ EPS replacement passing the lightweight density. For 7 days curing, brick with $25 \%$ POFA replacement have density of $1615.50 \mathrm{~kg} / \mathrm{m}^{3}$. For 28 days curing, brick with $15 \%, 20 \%$ and $25 \%$ POFA replacement have density of $1664.34 \mathrm{~kg} / \mathrm{m}^{3}, 1650.47 \mathrm{~kg} / \mathrm{m}^{3}$ and $1531.47 \mathrm{~kg} / \mathrm{m}^{3}$ respectively. Lastly, for 56 days of curing, brick with 15\%, $20 \%$ and $25 \%$ POFA replacement have density of $1671.33 \mathrm{~kg} / \mathrm{m}^{3}$, $1622.49 \mathrm{~kg} / \mathrm{m}^{3}$ and $1559.55 \mathrm{~kg} / \mathrm{m}^{3}$, respectively.

\subsection{Compressive strength}

Control sample recorded the highest compressive strength with reading of $28.6 \mathrm{MPa}$ at 56 days curing while the lowest strength recorded is $3.7 \mathrm{MPa}$ for mix with 50\% EPS replacement and 25\% POFA replacement at 7 days curing. Hence, the higher the EPS and POFA replacement, the lower the brick strength. However, the strength is still acceptable and the brick are still applicable for nonloadbearing structure.

Fig. 8 and Fig. 9 represent the result of 7 day, 28 days and 56 days compressive strength for all mix design. For 7 days curing, control brick recorded the highest strength with 25.73 $\mathrm{MPa}$ and brick with 50\% EPS and 25\% POFA replacement recorded the lowest strength with 3.7 MPa. The pattern of the result shows that the higher EPS and POFA replacement, the lower the brick strength. Fig. 8 shows the result for 7 days compressive strength for all mix design. For 7 days curing, control brick recorded the highest strength with $25.73 \mathrm{MPa}$ and brick with 50\% EPS and 25\% POFA 
replacement recorded the lowest strength with 3.7 MPa. The pattern of the result showed that the higher EPS and POFA replacement, the lower the brick strength.

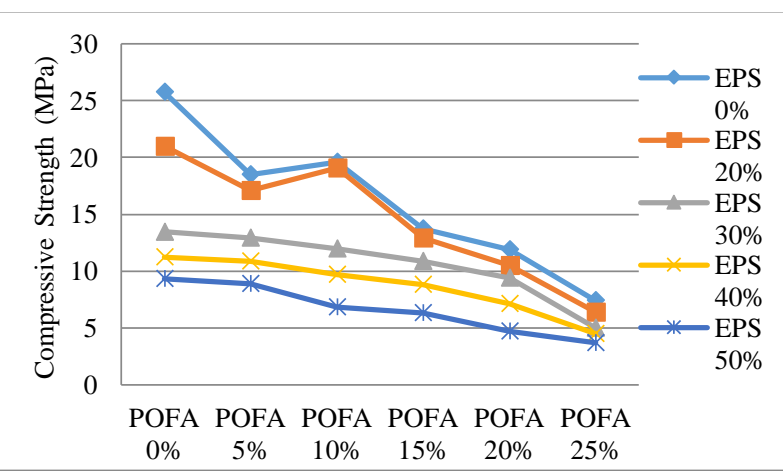

Fig. 8 Compressive strength graph of 7-days bricks sample.

Fig. 9 represent the result of 28 days compressive strength for all mix design. Control brick recorded the highest strength with $27.9 \mathrm{MPa}$ and brick with 50\% EPS and $25 \%$ POFA replacement recorded the lowest strength with $6.3 \mathrm{MPa}$. The pattern of the result showed that the higher EPS and POFA replacement, the lower the brick strength.

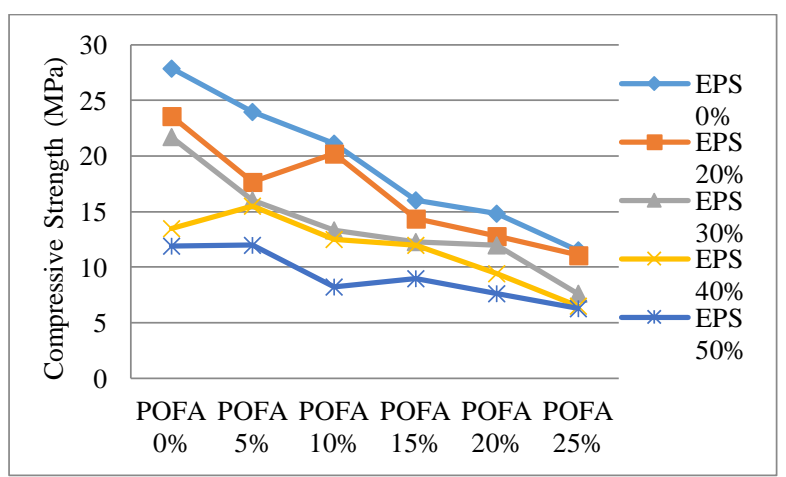

Fig. 9 Compressive strength graph of 28-days bricks sample.

Fig. 10 represent the result of 56 days compressive strength for all mix design. Control brick and brick with 0\% EPS replacement and 5\% POFA replacement recorded the same highest strength with 28.6 $\mathrm{MPa}$ and brick with 50\% EPS and 25\% POFA replacement recorded the lowest strength with 5.4 MPa. The pattern of the result showed that the higher EPS and POFA replacement, the lower the brick strength.

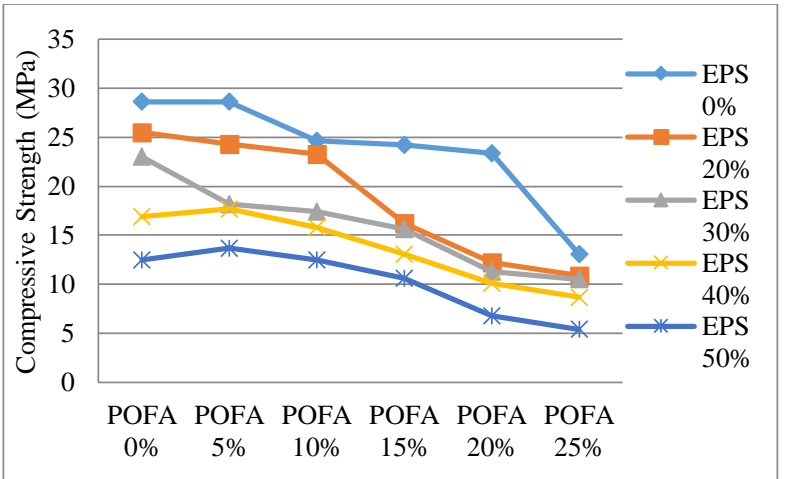

Fig. 10 Compressive strength graph of 56days bricks sample.

\subsection{Water absorption}

Bricks with 30 mixes design have been casted with various percentages of POFA and EPS. All results were tabulate as in Table 3 and illustrated in Fig. 11. From the result, it clearly seen that water absorption are increases when the OPC replaced with POFA. Then, the water absorption decreases when the sand is replaced with EPS. The maximum water absorption recorded is at E0P25 mixture which is $13.4 \%$ and the minimum water absorption is at E50P0 which is $4.37 \%$. From the results, it can be conclude that brick with higher EPS replacement have less void and brick with higher POFA replacement is more porous and have more voids.

In research conducted by Ling and Teo (2013), brick is produced with $30 \%$ EPS and RHA replacement between $(0-20 \%)$, the water absorption obtained are between (13-22\%). Thus, the result from this research is parallel with Ling and Teo (2013).

Table 3 Percentages of water absorption for various proportion at 28 days.

\begin{tabular}{|c|c|c|c|c|c|c|}
\hline \multirow{2}{*}{$\begin{array}{c}\text { EPS } \\
\%\end{array}$} & \multicolumn{7}{|c|}{$\begin{array}{c}\text { WOFA } \\
0 \%\end{array}$} & $\begin{array}{c}\text { POFA } \\
5 \%\end{array}$ & $\begin{array}{c}\text { POFA } \\
10 \%\end{array}$ & $\begin{array}{c}\text { POFA } \\
15 \%\end{array}$ & $\begin{array}{c}\text { POFA } \\
20 \%\end{array}$ & $\begin{array}{c}\text { POFA } \\
25 \%\end{array}$ \\
\hline $\begin{array}{c}\text { EPS } \\
0 \%\end{array}$ & 11.23 & 12.81 & 12.86 & 12.93 & 12.99 & 13.4 \\
\hline $\begin{array}{c}\text { EPS } \\
20 \%\end{array}$ & 6.95 & 8.47 & 11.41 & 11.7 & 12.1 & 12.4 \\
\hline $\begin{array}{c}\text { EPS } \\
30 \%\end{array}$ & 6.1 & 6.7 & 7.85 & 8.75 & 9.7 & 10.4 \\
\hline $\begin{array}{c}\text { EPS } \\
40 \%\end{array}$ & 5.82 & 5.91 & 7.37 & 7.46 & 7.63 & 7.73 \\
\hline $\begin{array}{c}\text { EPS } \\
50 \%\end{array}$ & 4.37 & 5.1 & 5.22 & 5.3 & 5.37 & 5.43 \\
\hline
\end{tabular}




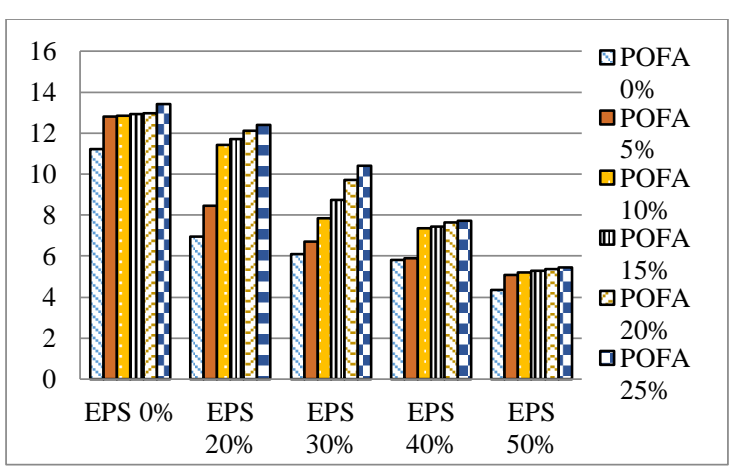

Fig. 11 Percentages of water absorption for different percentage of EPS and POFA replacement at 28 days.

\subsection{Conclusion}

The brick with 30\%, 40\% and 50\% EPS replacement have density below $1680 \mathrm{~kg} / \mathrm{m} 3$ and categorized as lightweight brick. Replacement of EPS gives large difference of the brick weight as the EPS is very low in density. The replacement of POFA also affect the density as it density is lower than OPC.

All of the brick with various EPS and POFA replacement have acceptable strength and the maximum EPS and POFA replacement at 7 days curing is still acceptable for nonloadbearing structure. Brick with lowest strength recorded the strength of $3.7 \mathrm{MPa}$. Minimum strength stated for nonloadbearing brick from ASTM C90-06b standard is only 3.45 MPa. The bricks containing EPS and POFA replacement resulted in samples with lower density and lower compressive strength compared to control sample with 0\% EPS and 0\% POFA replacement. Generally, material with lower density have lower strength.

As a conclusion, the brick with maximum waste replacement at 25\% POFA and 50\% EPS gives the best result as it have highest waste content and it can achieve the lightweight and compressive strength requirement for a lightweight brick.

\section{REFERENCES}

[1] Rahman M.E., Boon A.L., Muntohar, A.S., Tanim M.N.H., Pakrashi, V., (2014) Performance of mansory blocks incorporating Palm Oil Fuel Ash, J. Clean. Prod. 78, pp. 195-201.

[2] Singh S.B., Munjal P., (2017) Bond strength and compressive stress-strain characteristics of brick Masonry, Building Engineering 9, pp. 10-16.
[3] Zhang L., (2013). Production of bricks from waste materials - A review. Constr Build Mater. 47, pp. 643-655.

[4] Alsubari B., Shafigh P., Jumaat M.Z., (2016). Utilization of high-volume treated palm oil fuel ash to nable self-compacting concrete. J. Clean. Prod. 137, pp. 982-996.

[5] Tabassum R.K., Khadwal A., (2015). A Brief Review on Geopolymer Concrete. Int. J. of Adv. Res. in Edu. Technol. Vol. 2, Issue 3.

[6] Zeyad A.M., Megat Johari M.A., Tayeh B.A., Yusuf M.O., (2016). Efficiency of treated and untreated palm oil fuel ash as a supplementary binder on engineering and fluid transport properties of high-strength concrete. Constr. Build. Mater. 125, pp. 1066-1079.

[7] Al-Oqla, Faris M., Sapuan S.M., (2014). Natural fiber reinforced polymer composites in industrial applications: feasibility of date palm fibers for sustainable automotive Industry. J. Clean. Prod. 66, pp. 347-354.

[8] Raut A.N., Gomez C.P., (2015). Thermal and mechanical properties of oil palm fibre reinforced mortar utilizing palm oil fly ash as a complementary binder. Constr. Build. Mater. 126, pp. 476-483.

[9] Munir A., Abdullah, Huzaim, Sofyan, Irfandi, Safwan, (2015). Utilization of palm oil fuel ash (POFA) in producing lightweight foamed concrete for nonstructural building material. Procedia Engineering, 125, pp. 739-746.

[10]Ling I.H and Teo D.C.L., (2013). EPS RHA Concrete Bricks - A New Building Material, Jordan J. of Civ. Eng. Vol. 7, No. 4.

[11]Musab A.S.A. (2016). The Mechanical And Physical Properties Of Concrete Containing Polystyrene Beads As Aggregate and Palm Oil Fuel Ash As Cement Replacement Material. Master Thesis, Universiti Tun Hussein Onn Malaysia.

[12]Xu Y, Jiang L, Xu J, Li Y. (2012) Mechanical properties of expanded polystyrene lightweight aggregate concrete and brick. Constr Build Mater., 27, pp. 3238.

[13] Adnan, S.H. , Musab, A.S.A. Jamellodin, Z. (2017). The Mechanical and Physical Properties of Concrete Containing Polystyrene Beads As Aggregate and Palm Oil Fuel Ash as Cement Replacement Material, AIP Conference Proceedings, 1891, 020016. 